MICHAE GNATOWSKI (Białystok)

\title{
KULISY RADZIECKICH STARAŃ \\ O PONOWNE WŁĄCZENIE REGIONU BIAŁOSTOCKIEGO W SKŁAD ZSRR (1942-1944)
}

W udostępnianych ostatnio radzieckich źródłach, część których publikuję w niniejszym tomie "Studiów...", są informacje o kulisach radzieckich starań o ponowne włączenie regionu białostockiego w skład ZSRR. Jak wiadomo po 17 września 1939 r. w wyniku radzieckiej agresji, dokonanej w zmowie $\mathrm{z}$ hitlerowskimi Niemcami, ZSRR zajął ziemie wschodnie Polski, w tym i Białostocczyznę i włączył je w skład swego państwa. 28 września 1939 r. Niemcy i ZSRR dokonały formalnego podziału ziem polskich, podpisując układ o granicach i przyjaźni.

Po wybuchu wojny radziecko-niemieckiej 22 czerwca 1941 r. i zajęciu tych ziem przez Niemców ZSRR utracił kontrolę nad wschodnimi ziemiami polskimi i pomimo że anulował porozumienia radziecko-niemieckie o podziale ziem polskich i podpisał porozumienie z polskim rządem na uchodźstwie, nie zrezygnował z roszczeń do nich. Pomimo sugestii w rozmowach z rządem polskim o możliwości zwrotu Białostocczyzny Polsce za zgodę Polaków na zajęcie wschodnich ziem polskich, podejmowano energiczne działania w celu włączenia ponownie tego regionu do ZSRR.

W artykule przedstawiam szczegółowo działania radzieckich władz w celu przywrócenia kontroli nad regionem białostockim. Działania te trwały przez cały czas a $\dot{z}$ do wyzwolenia regionu spod niemieckiej okupacji. Starano się przede wszystkim rozbudowywać na tych ziemiach struktury terenowe radzieckiego podziemia a zwłaszcza podziemne komitety partyjne i komsomolskie oraz kierować tu grupy dywersyjno-zwiadowcze Narodowego Komisariatu Bezpieczeństwa Państwowego (NKGB). Ich podstawowym zadaniem było opanowanie terenu i zniszczenie polskiego podziemia wszystkimi dostępnymi środkami, włącznie $z$ walką zbrojną. 
Pod pojęciem „region białostocki” i zamiennie "Białostocczyzna” rozumieć należy obszary regionu w granicach dowojennego województwa białostockiego, sprzed l kwietnia 1939 r., a pod pojęciem „ziemie północno-wschodnie" dowojenne województwa: białostockie, nowogródzkie, poleskie i wileńskie w ówczesnych ich granicach.

Ziemie północno-wschodnie Polski, włączone po 17 września 1939 r. do ZSRR, traktuję jako polskie: w 1939 r. zajęte i okupowane przez ZSRR a następnie od lipca 1941 r. przez Niemców. W radzieckich źródłach i w białoruskiej literaturze są one traktowane jako białoruskie i wszystkie kwestie ich dotyczące rozpatrywane są w granicach wprowadzonego tu na początku 1940 r. radzieckiego podziału administracyjnego, tj. w podziale na obwody i rejony. Traktując zmiany dokonane na tych ziemiach w 1939 r. za nieuzasadnione prawnie, będę jednak ze względów praktycznych posługiwał się ówczesnym podziałem administracy jnym. Według tego podziału bowiem również w latach okupacji niemieckiej powoływano na tych ziemiach ośrodki konspiracyjnych władz radzieckich, struktury partyzanckie i kierownictwa grup operacyjnych.

\section{Zmiany w radzieckiej polityce w ,sprawie polskiej" i ich konsekwencje dla regionu}

Problemy radzieckiej polityki wobec Polski i Polaków w latach II wojny światowej były już w polskiej literaturze wielokrotnie omawiane ${ }^{1}$. Przypomnę zatem w skrócie tylko podstawowe kwestie.

W radzieckiej polityce wobec Polski i Polaków w omawianym okresie historycy wyodrębniają trzy podstawowe okresy.

Pierwszy okres trwał od 17 września 1939 r. do 22 czerwca 1941 r. W okresie tym, ujmując rzecz w skrócie, rząd ZSRR po dokonaniu wspólnie z Niemcami podziału ziem polskich odmawiał Polakom prawa do niepodległościowego bytu oraz w sposób brutalny, wspólnie z Niemcami, zwalczał dążenia niepodległościowe Polaków, których na zajętych terenach traktował jako kolonizatorów lub spolonizowanych Białorusinów i Ukraińców.

Drugi okres trwał od 30 lipca 1941 r. do 25 kwietnia 1943 r. W okresie tym ZSRR zagrożony niepowodzeniami na froncie radziecko-niemieckim

1 Por. m.in. A. Głowacki, Sowieci wobec Polaków na ziemiach wschodnich II Rzeczypospolitej 1939-1941, Eódź 1997. 
uznał państwo polskie i nawiązał stosunki dyplomatyczne $\mathrm{z}$ polskim rządem na uchodźstwie, podpisując znane umowy międzypaństwowe. Polacy w ZSRR z „obcej masy", przeznaczonej do usunięcia, stali się obcokrajowcami, w pewnym sensie na prawach szczególnych. Powstawały bowiem w ZSRR struktury polskich władz cywilnych (delegatury ambasady RP, mężowie zaufania), system pomocy społecznej i narodowe wojsko. „Sprawa polska", traktowana dotąd przez ZSRR jako "problem wewnętrzny" tego państwa, została w pełni „umiędzynarodowiona”. ZSRR znalazł się wspólnie $\mathrm{z}$ Polską $\mathrm{w}$ koalicji antyfaszystowskiej. Rząd ZSRR jednak, pomimo że anulował porozumienia radziecko-niemieckie z 1939 r., nie zrezygnował ze wschodnich ziem polskich i wywierał presję na rząd polski na uchodźstwie, by ten zaakceptował zmiany granicy wschodniej dokonane w 1939 r., na co Polska nie mogła się zgodzić. Komplikowało to w istotny sposób wykonanie zawartych porozumień i wspólną walkę z Niemcami. Równolegle z układaniem stosunków $\mathrm{z}$ rządem polskim na uchodźstwie ZSRR zaczął odbudowywać ruch komunistyczny w Polsce jako element nacisku i ewentualną alternatywę, gdyby rząd polski na uchodźstwie nie zechciał zaakceptować radzieckich żądań.

Trzeci okres trwał od 25 kwietnia 1943 r. do 21 lipca 1944 r., tj. do powołania Polskiego Komitetu Wyzwolenia Narodowego. W okresie tym rząd ZSRR rozwiązał „sprawę polską" według własnego scenariusza, poza rządem polskim na uchodźstwie. ZSRR postawił na komunistów, ponieważ ci godzili się na zmiany granicy wschodniej i gwarantowali wpływy ZSRR w Polsce, zgodnie $z$ jego imperialnymi dążeniami. Odtąd radziecka polityka zmierzała już wprost, z jednej strony - do nieograniczonego wspierania komunistów polskich i sił $\mathrm{z}$ nimi związanych i $\mathrm{z}$ drugiej - do dyskredytowania i zwalczania wszystkimi środkami rządu polskiego na uchodźstwie i wspierających go sił w kraju, włącznie $z$ oskarżaniem strony polskiej o współpracę z Niemcami.

Zmiana w 1943 r. radzieckiej polityki miała dla omawianych kwestii kluczowe znaczenie. Do tego czasu władze radzieckie powstrzymywały się od tworzenia struktur politycznych na wschodnich ziemiach Polski, zwłaszcza na Białostocczyźnie. Partyzantce w tym czasie stawiano głównie zadania militarne i zwiadowcze, związane $z$ potrzebami frontu wschodniego. Nie występowano też otwarcie przeciwko polskiemu podziemiu, działającemu tu od pierwszych dni okupacji. Zrezygnowano nawet $z$ tworzenia „bolszewickiego w treści i polskiego w formie" ruchu partyzanckiego.

Inne zadanie postawiono przed radzieckim podziemiem na północno-wschodnich ziemiach Polski po przerwaniu 25 kwietnia 1943 r. (faktycznie 
zerwaniu) stosunków dyplomatycznych z polskim rządem na uchodźstwie, pod obłudnym pretekstem tzw. „sprawy katyńskiej”.

\section{Polityczne cele radzieckiego podziemia na ziemiach północno-wschodnich Polski w latach 1943-1944}

W radzieckiej literaturze przez wiele lat cele radzieckiego podziemia na polskich ziemiach traktowano wybiórczo, eksponując przesadnie walkę z niemieckim okupantem i pomijając zasadniczy cel - opanowanie terenu i rozprawę z polskim podziemiem. Pomijano fakt, że działalność tego podziemia podyktowana była głównie względami politycznymi. Z tego powodu nakazywano przede wszystkim organizować komitety partyjne i rozwijać pracę polityczno-propagandową. Równocześnie intensyfikowano działalność na ziemiach polskich służb specjalnych. Cele polityczne spowodowały, że wprowadzano tu absurdalną $w$ partyzantce, $t z w$. rejonizację, tj. równomierne rozmieszczanie partyzanckich brygad i oddziałów w poszczególnych rejonach niezależnie od sytuacji i warunków terenowych oraz tworzenie komitetów rejonowych Komunistycznej Partii (bolszewików) Białorusi [KP(b)B] i Leninowskiego Komunistycznego Związku Młodzieży Białorusi [LKZMB]. Utrzymywana była też w partyzantce funkcja komisarza, który na równi $z$ dowódcą sprawował pełnię władzy i czuwał nad rozbudowywanym w terenie aparatem agitacyjno-propagandowym (redakcje gazet, grupy propagandowe, lektorzy). W formacjach partyzanckich tworzono również struktury władz bezpieczeństwa i wywiadu politycznego. Zadania te spełniały w zgrupowaniach i brygadach wydziały specjalne (osobyje otdieły), które w oddziałaçh i kompaniach miały swoich pełnomocników. Na wszystkich szczeblach struktur partyzanckich działały siatki informatorów. Rozbudowywano też sieć informatorów i agentów w terenie. Ponadto nad lojalnością "obywateli ZSRR" wobec partii i władzy radzieckiej czuwały oddziały i grupy specjalne NKGB, kierowane tu zza linii frontu, o czym będzie jeszcze mowa.

W polskich dokumentach odnotowano, że radzieckie podziemie dążyło do stwarzania wrażenia „wszechobecności”, zarówno na wsi jak i w mieście. Kierownictwo radzieckiego podziemia wydawało zarządzenia, które miały obowiązywać także miejscową ludność, regulowano sprawy wg radzieckiego prawa, obchodzono święta państwowe, w bazach partyzanckich organizowano szkoły. Tam, gdzie zdołano się umocnić, powoływano partyzanckie komendantury, aktywy, które miały regulować życie społeczne i gospodarcze, 
np. pomagano $\mathrm{w}$ przeprowadzaniu siewów czy zbiorów z pól, przekazując wybranym gospodarzom konie i zboże lub sprzęt rolniczy. W radzieckich źródłach jest sporo informacji o rozmiarach okazywanej pomocy, lecz nie ma żadnych informacji o tym, skąd partyzanci radzieccy mieli przekazywane dobra. Przecież wszystkie niemieckie magazyny były już rozgrabione. Po prostu odbierano jednym i dawano „swoim", a więc zajmowano się dystrybuc ją dóbr, zgodnie z radziecką „sprawiedliwością".

Działalność taka wynikała zarówno $\mathrm{z}$ radzieckiego systemu, jak i potrzeb bieżącej-polityki. Można więc powiedzieć, że radzieckie podziemie na tych ziemiach spełniało specjalną misję polityczną, którą w skrócie można określić jako demonstrowanie obecności i siły władzy radzieckiej oraz wymuszanie posłuszeństwa i lojalności. W praktyce walka z Niemcami, o której tak głośno było w propagandzie, schodziła na plan dalszy. Formacje partyzanckie przekształcone zostały w „partyjne wojsko”, służące przede wszystkim do walki z polskim podziemiem oraz z politycznymi i klasowymi przeciwnikami władzy radzieckiej. Potwierdzają to liczne dokumenty radzieckiego kierownictwa, m.in. tajny okólnik KC KP(b)B z 22 czerwca 1943 r. „O wojskowo-politycznych zadaniach pracy w zachodnich obwodach BSRR", rozesłany w teren ${ }^{2}$. W okólniku tym radzieckie podziemie zobowiązane zostało do niszczenia wszystkimi dostępnymi środkami polskiego podziemia na ziemiach wschodnich Polski. Zalecenie to spowodowało liczne konflikty i doprowadziło do zbrojnych potyczek.

Cele polityczne i metody działania radzieckiego podziemia faktycznie wykluczały jakąkolwiek współpracę z innymi nưrtami podziemia, które traktowano na polskich ziemiach jako bezprawne. Żądano od nich bezwarunkowego podporządkowania się, wyrzeczenia się swoich racji i reprezentowania wyłącznie interesów ZSRR. Odmowę natomiast traktowano jako akt wrogi wobec ZSRR, rozbijanie jedności frontu antyfaszystowskiego i działanie na rzecz Niemców.

Znikoma baza społeczna władz radzieckich na północno-wschodnich ziemiach Polski, zwłaszcza wśród miejscowej ludności, oraz duże wpływy polskiego podziemia niepodległościowego i ożywienie dążeń niepodległościowych Białorusinów, wspierane przez cywilne władze okupacyjne Niemiec, nie stwarzały specjalnych warunków do umacniania radzieckich wpływów. Dlatego radzieckie kierownictwo opracowało szczegółowe plany, których ce-

2 Narodowe Archiwum Republiki Białoruś (NARB) w Mińsku, zesp. 4, spr. 3, t. 1243, k. $78-90$. 
lem było ponowne opanowanie tych ziem i ich sowietyzacja. Plany te obejmowały także Białostockie, które radzieckie kierownictwo traktowało jako „radziecki teren wymagający specjalnej troski”. Po pierwsze - dlatego, że wymagały tego określone wyżej cele radzieckiego podziemia i po drugie - że działało tu silnie rozbudowane i wspierane przez miejscową ludność polskie podziemie, a wręcz znikome wpływy miało podziemie radzieckie. Starano się zatem ten stan jak najszybciej zmienić.

\section{Partyjni organizatorzy radzieckiego podziemia w regionie}

Pierwsze prace związane $\mathrm{z}$ odbudową wpływów $\mathrm{w}$ regionie białostockim podjęto już jesienią 1942 r. 8 października 1942 r. wznowił działalność w Moskwie Komitet Obwodowy $\mathrm{KP}(\mathrm{b}) \mathrm{B}$ w Białymstoku, w dowojennym składzie. Do Moskwy wezwani zostali sekretarze: A. P. Elman, A. A. Kilbin i I. S. Krawczenko. 13 marca 1943 r. skład komitetu został poszerzony o I. N. Stryżaka - sekretarza Komitetu Obwodowego LKZMB, N. S. Gridasowa - naczelnika Zarządu Obwodowego Narodowego Komitetu Spraw Wewnętrznych (NKWD), W. S. Samutina - redaktora obwodowej gazety, W. R. Romanowa - sekretarza Komitetu Miejskiego KP(b)B w Białymstoku, a 13 lipca 1943 r. również o D. K. Sukaczowa - dotychczasowego pełnomocnika KC KP(b)B na obwód białostocki. Przygotowany został też szczegółowy plan działania w obwodzie na okres zimy 1942/43 r. Przewidziano w nim szeroki zakres działań organizacyjnych, określono skład imienny osób, które należy skierować na tyły, oraz potrzebną ilość broni i sprzętu. Wśród kierowników grup organizatorskich i aktywu partyjnego, przewidzianych do skierowania na tyły, były głównie osoby, które pracowały już w obwodzie w latach 1939-1941. Nie omawiam szczegółów tego planu, gdyż nie był on realizowany. Było to przedsięwzięcie w ówczesnych warunkach nierealne. Władze nie mogły wówczas przekazać do dyspozycji komitetu takiej ilości ludzi, broni i innego sprzętu niezbędnego w konspiracji. Nie miały także możliwości przetransportowania takiej ilości ludzi i sprzętu na tyły wroga.

Ważne decyzje w sprawie działalności radzieckiego podziemia na omawianych terenach podjęło $\mathrm{V}$ Plenum $\mathrm{KC} \mathrm{KP(b)B}$, obradujące w Moskwie w dniach 26-28 lutego 1943 r. Przede wszystkim zalecono podziemnym komitetom obwodowym. KP(b)B z terenów wschodnich Białorusi, aby okazały daleko idącą pomoc w rozwoju podziemia w zachodnich obwodach Białorusi i na ziemiach polskich. Główną uwagę zwrócono na rozszerzenie pracy 
masowo-politycznej i propagandowej, zwłaszcza na ziemiach polskich. I sekretarz KC KP(b)B P. K. Ponomarenko w obszernym referacie i w przemówieniu końcowym wiele miejsca udzielił „sprawie polskiej”, wskazując jednoznacznie, że trzeba podjąć walkę $z$ "polskimi nacjonalistami” 3 .

Do nowych zadań dostosowano struktury KP(b)B. Odstąpiono od zasad statutowych wzmacniając centralizm i wprowadzając w zachodnich obwodach podwójne komitety obwodowe. Obok ewakuowanych komitetów działających na obszarach niezajętych przez Niemców powoływano podziemne komitety obwodowe i kierowano je na tyły wroga. Miały one stanowić centra kierownicze podziemia w obwodach. Wysyłano też do rejonów pełnomocników $\mathrm{KC} \mathrm{KP}(\mathrm{b}) \mathrm{B}$, zadaniem których było stworzenie podziemnych komitetów rejonowych. W taki sam sposób zalecono powoływać komitety obwodowe, miejskie i rejonowe LKZMB - pierwszego pomocnika partii.

Od wiosny 1943 r. przystąpiono już do praktycznego uruchamiania ośrodków kierowniczych podziemia radzieckiego na wschodnich ziemiach Polski. W marcu 1943 r. przerzucono do obwodu baranowickiego grupę organizatorów z W. Czernyszewem - I sekretarzem Podziemnego Komitetu Obwodowego KP(b)B na czele, do obwodu białostockiego - D. Sukaczowa, pełnomocnika KC KP(b)B i komitetu obwodowego, a do obwodu brzeskiego grupę aktywu pod kierownictwem S. Sikorskiego - I sekretarza Podziemnego Komitetu Obwodowego KP(b)B. W tym samym czasie, co D. K. Sukaczow, zrzucony został na tyły z zadaniem przejścia do obwodu białostockiego T. N. Stryżak - pełnomocnik KC LKZMB.

Latem 1943 r. zapadły kolejne decyzje w sprawie rozbudowy podziemia w obwodzie białostockim. 27 lipca tego roku powołany został w Moskwie, obok już istniejącego komitetu obwodowego KP(b)B, Białostocki Podziemny Komitet Obwodowy (BPKO). I sekretarzem Komitetu został Wasyl Jemieljanowicz Samutin, ps. Jemieljanow. Wybór W. J. Samutina na to stanowisko nie był przypadkowy. Znał on stosunki na tym terenie i język polski. W połowie lat 30. był sekretarzem komitetu okręgowego Komunistycznej Partii Zachodniej Białorusi (KPZB) w Białymstoku. W skład komitetu weszli: D. K. Sukaczow i T. N. Stryżak - skierowani wcześniej na tyły, a 23 listopada 1943 r. również gen. F. F. Kapusta - szef Obwodowego Sztabu Partyzanckiego i S. Majchrowicz - redaktor konspiracyjnej gazety „Biełostokskaja Prawda".

3 Tamże, spr. 20, t. 214 (stenogram). 
Po instruktażu w KC KP(b)B 3 sierpnia 1943 r. W. J. Samutin wraz z grupa aktywu przerzucony został samolotem do obwodu mińskiego, gdzie na polecenie Białoruskiego Sztabu Ruchu Partyzanckiego (BSzRP) formowano Białostockie Zgrupowanie Partyzanckie (BZP). Wraz z nim powrócił z Moskwy gen. Filip Kapusta, wyznaczony na dowódcę zgrupowania, i kpt. Iwan Sienkiewicz powołany na szefa sztabu. Dołączyli do nich również pracownicy redakcji i komitetu obwodowego KP(b)B. Natychmiast po wylądowaniu nawiązali oni kontakt $\mathrm{z}$ Mińskim Podziemnym Komitetem Obwodowym $\mathrm{KP}(\mathrm{b}) \mathrm{B}$ i podjęli prace organizacyjne związane $\mathrm{z}$ formowaniem zgrupowania i przygotowaniami do rajdu na Białostocczyznę.

Trwały też dalsze prace na zapleczu frontu. KC KP(b)B i białostocki Komitet Obwodowy $\mathrm{KP}(\mathrm{b}) \mathrm{B}$ w Moskwie przygotowywały i wysyłały na obszary Białostocczyzny specjalne grupy organizatorskie. We wrześniu 1943 r. skierowano grupy: P. P. Bastuna, W. W. Kundowicza, J. M. Owsiejczyka, A. A. Stomy, A. G. Szłamanowa, J. S. Szurmana i A. D. Tracewskiego. Kierownicy grup organizatorskich spełniali funkcje pełnomocników KC KP(b)B na poszczególne rejony, a następnie objęli funkcje sekretarzy podziemnych komitetów partyjnych. Przerzucane na tyły grupy organizatorskie wyposażone zostały $\mathrm{w}$ niezbędny sprzęt i radiostacje, co zapewniało utrzymanie stałej łączności z centralnym ośrodkiem kierowniczym i ze zgrupowaniem w czasie rajdu. Otrzymały one też dodatkowe uzbrojenie dla oddziałów, które miały być tworzone na miejscu przeznaczenia. Część grup wyszła do obwodu już wcześniej, m.in. grupa D. N. Gordijenki do rejonu grajewskiego. Powołanie BZP i skierowanie grup organizatorskich podziemia na Białostocczyznę nie kończyło procesu przerzucania oddziałów i grup organizatorskich na zachód. Trwał on aż do wyzwolenia.

Organiz̧atorzy podziemia kierowali się w działalności przyjętymi w czerwcu 1943 r. specjalnymi wytycznymi KC KP(b)B i BSzRP. Stanowiły je m.in. wspomniany okólnik „O wojskowo-politycznych zadaniach pracy w zachodnich obwodach BSRR" oraz specjalna uchwała KC KP(b)B "O dalszym rozwoju ruchu partyzanckiego w zachodnich obwodach Białorusi". Określały one przedsięwzięcia organizacyjne mające na celu szybkie przekształcenie ruchu partyzanckiego w obwodach białostockim i brzeskim w ruch masowy, rozszerzenie pracy politycznej wśród ludności i wyeliminowanie wpływów polskiego podziemia, określanego jako „nacjonalistyczne".

Uchwała KC KP(b)B z 22 czerwca 1943 r. „O dalszym rozwoju ruchu partyzanckiego..." zadania dla obwodów białostockiego i brzeskiego formułowała następu jąco: 
„a) w okresie od czerwca do sierpnia (1943 r.) powołać we wszystkich rejonach podziemne partyjne i komsomolskie komitety, utrzymujące stałą łączność z KC i przebywające przy jednym z największych i najsprawniejszych oddziałów partyzanckich;

b) przerzucić $z$ innych obwodów Białorusi do obwodów białostockiego i brzeskiego 40 oddziałów partyzanckich, po jednym do każdego rejonu, zwracając uwagę przy powoływaniu na specyfikę rejonu, w którym mają one działać, włączając do nich obowiązkowo po kilku oddanych nam Polaków i Białorusinów, znających język polski, oraz pracowników aparatu partyjnego pracujących do wojny w tych obwodach...;

c) skompletować i wysłać do wszystkich rejonów zachodnich obwodów, publikowane w prasie, dokumenty polityczne o stosunkach polsko-radzieckich, przedstawiające stanowisko rządu radzieckiego w sprawie granicy państwowej z Polską;

d) wzmocnić kadrowo redakcje gazet w obwodach białostockim i brzeskim, zwiększyć format i nakład gazet obwodowych. Uruchomić dodatkowo wydawanie w obu obwodach po 5 gazet rejonowych w języku rosyjskim i po 2 gazety w języku polskim oraz określić zakres ich kolportowania;

e) w celu zapewnienia optymalnej efektywności i wiarygodności wydawanych w zachodnich obwodach gazet polecić Wydziałowi Agitacji i Propagandy opracowanie wytycznych dla redaktorów tych gazet oraz plan okresowego przekazywania artykułów programowych" 4 .

Zobowiązano także kierownictwo LKZMB do opracowania planu działań zmierzających do aktywizacji działalności wśród młodzieży w zachodnich obwodach.

Białostocki podziemny komitet obwodowy $\mathrm{KP}(\mathrm{b}) \mathrm{B}$, po przybyciu na tereny okupowane i założeniu stałej bazy w Puszczy Lipiczańskiej, starał się spełniać funkcje ośrodka kierowniczego podziemia na Białostocczyźnie. Znajdował się on jednak poza jej obszarami i jego oddziaływanie było znacznie ograniczone. Podejmował on jednak liczne działania zmierzające do rozwiązywania spraw podziemia i zadań, jakie stały przed nim. Jak podaje W. J. Samutin, od jesieni 1943 r. działalność komitetu koncentrowała się na dwóch podstawowych kierunkach:

- tworzeniu sieci podziemnych komitetów KP(b)B i LKZMB w rejonach i dużych miastach; 
- dążeniu do przejścia formacji partyzanckich na wyznaczone obszary działania w swoich rejonach ${ }^{5}$.

Część komitetów rejonowych rozpoczęła działalność już w trakcie rajdu zgrupowania. We wrześniu 1943 r. rozpoczęły działalność podziemne komitety rejonowe $\mathrm{KP}(\mathrm{b}) \mathrm{B}$ śniadowski i sopociński. Ich organizatorami i sekretarzami zostali, skierowani do tych rejonów, pełnomocnicy $\mathrm{KC} \mathrm{KP(b)B.}$ W październiku i listopadzie 1943 r. rozpoczęły działalność kolejne komitety rejonowe, m.in. augustowski komitet międzyrejonowy, obejmujący również rejon grajewski. W grudniu 1943 r. rozpoczął działalność brański podziemny komitet międzyrejonowy $\mathrm{KP}(\mathrm{b}) \mathrm{B}$, który obejmował też rejon ciechanowiecki. W 1944 r. nawiązali kontakt z komitetem obwodowym KP(b)B kolejni pełnomocnicy KC KP(b)B i podjęli działalność jako sekretarze komitetów rejonowych: w marcu A. A. Stoma - sekretarz czyżewskiego komitetu międzyrejonowego, obejmującego również rejon zambrowski, i w maju A. F. Sokolczyk - sekretarz łomżyńskiego komitetu międzyrejonowego, obejmującego również rejony jedwabnieński i kolneński. W lipcu 1944 r. formalnie w obwodzie białostockim było 14 komitetów $\mathrm{KP}(\mathrm{b}) \mathrm{B}$ : obwodowy, 4 międzyrejonowe i 9 rejonowych ${ }^{6}$.

Ważną "transmisją partii” na młodzież był LKZMB - organizator młodzieżowego podziemia. Podziemie to organizowano w obwodzie już od lata $1943 \mathrm{r}$. W tym czasie na wschodnie obszary przybył z obwodu mińskiego z grupą organizatorów T. N. Stryżak, pełnomocnik KC LKZMB. Wkrótce przybyli też inni działacze LKZMB, kierowani tu jako pełnomocnicy KC LKZMB na poszczególne rejony. W czerwcu zatwierdzony został skład osobowy BPKO LKZMB. Weszło do niego 3 sekretarzy i 8 członków. Członkowie otrzymali przydział obszarów działania, powołano pełnomocników na poszczególne rejony i jednocześnie przystąpiono do powoływania komitetów rejonowych. Do końca 1943 r. powołano 17 komitetów rejonowych i 2 miejskie.

W sierpniu 1943 r. powołane zostały podziemne komitety rejonowe LKZMB dla rejonów brańskiego i skidelskiego, w listopadzie - komitety miejskie w Białymstoku i Grodnie, a także rejonowe dla rejonów: bielskiego, grodzieńskiego, świsłockiego, łomżyńskiego, sopoćkińskiego, śniadowskiego

5 W. J. Samutin, So wsiej mieroj partijnoj otwietstwiennosti, w: Partijnoje podpolie $w$ Bietorussii 1941-1944. Wilejskaja, Baranowiczskaja, Pinskaja, Brestskaja, Bietostokskaja obłasti, Mińsk 1986, s. 355-356.

6 Podpolnyje partyjnyje organy Kompartii Biełorussii $w$ gody Wielikoj otieczestwiennoj wojny, 1941-1944, Mińsk 1975, s. 52. 
i zambrowskiego, w styczniu 1944 r. - ciechanowieckiego, czyżewskiego i sokólskiego, w kwietniu - białostockiego i krynkowskiego oraz w maju - knyszyńskiego. Wszystkie komitety przebywały w brygadach i oddziałach partyzanckich, a więc miały - podobnie jak komitety $\mathrm{KP}(\mathrm{b}) \mathrm{B}$ - utrudniony kontakt ze „swoimi” obszarami działania.

W lipcu 1944 r. - według sprawozdań - LKZMB obejmował zasięgiem swojej działalności znaczne obszary regionu i sporą liczbę partyzantów. Działały w tym czasie: komitet obwodowy, 2 podziemne komitety miejskie (białostocki i grodzieński) oraz 21 komitetów rejonowych. Kierowały one 279 organizacjami terenowymi, 68 młodzieżowymi organizacjami antyfaszystowskimi i 96 organizacjami w brygadach i oddziałach partyzanckich. W radzieckiej literaturze podaje się, że w organizacjach tych było ponad 2600 członków, w tym w organizacjach terenowych $1511 \mathrm{i}$ w partyzanckich formacjach 1115. Członkowie LKZMB stanowili w zgrupowaniu 26,3\% składu osobowego, a łącznie z członkami i kandydatami KP(b)B - prawie $40 \%$ ?.

Podziemne komitety partyjne i komsomolskie obejmowały znaczną część dowojennych rejonów, lecz w praktyce ich oddziaływanie było niewielkie. Sekretarze i pozostali członkowie komitetów przebywali stale w brygadach i oddziałach, które znajdowały się w partyzanckich bazach, znacznie oddalonych od ich rejonów. Brak znajomości terenu i wsparcia u miejscowej ludności powodował, że również wysyłani przez sekretarzy do swoich rejonów emisariusze nie byli w stanie pokonać wyznaczonych tras i albo ginęli w potyczkach z Niemcami, albo zawracali do baz położonych na wschodnich obszarach. Również wydawana przez komitety prasa, odezwy i ulotki rzadko docierały do wyznaczonych terenów.

\section{Komitety i organizacje antyfaszystowskie - oparciem dla radzieckich działań $\mathrm{w}$ terenie}

Do struktur radzieckiego podziemia włączone zostały też komitety i organizacje antyfaszystowskie. Powstawały one w latach 1941-1942, głównie na Polesiu i w Białostockiem, z inicjatywy b. działaczy KPZB. Na Polesiu organizowali je już w $1941 \mathrm{r}$. wysłannicy KC KP(b)B J. Urbanowicz, znany na tych terenach działacz KPZB, i I. Żyszko, którzy latem 1941 r. zostali

7 Podpolnyje komsomolskije organy Biełorussii $w$ gody Wielikoj otieczestwiennoj wojny, 1941-1944, Mińsk 1976, s. 65. 
skierowani na tyły wroga. Rozwinęli oni' tu aktywną działalność, powołując Komitet Walki z Niemieckim Okupantem, który tworzył swoje ogniwa w rejonach i skupiał na początku 1943 r. w swoich szeregach kilkuset działaczy ${ }^{8}$.

W ogniwach terenowych radzieckiego podziemia zdania o roli komitetów antyfaszystowskich były podzielone. Część działaczy podziemia uważała, że działalność tych organizacji, ze względu na udział w nich ludzi niesprawdzonych lub napiętnowanych oskarżeniem o prowokację (byli działacze KPZB), stanowi okazję do przenikania do podziemia prowokatorów i stanowi istotne zagrożenie. Inni uważali, że była to dobra forma organizacji podziemia, lecz jedynie w okresie do powstania komitetów partyjnych, które teraz powinny przejąć ich funkcje i rozwijać dalszą działalność już na czysto bolszewickich zasadach. Byli też i tacy, którzy uważali, że komitety powinny pozostać i działać nadal jako „pas transmisyjny” komitetów partyjnych.

24 czerwca 1943 r. problem komitetów antyfaszystowskich był omawiany na posiedzeniu Biura KC KP(b)B, na którym zapadła decyzja akceptująca komitety jako jedną $z$ form organizacji radzieckiego podziemia w zachodnich obwodach BSRR.

W notatce $z$ obrad biura CK KP(b)B stwierdza się: „Te bezpartyjne organizacje trzeba zachować i rozwijać ich działalność. Stanowią one dobry, korzystny dla nas środek włączania do walki z faszyzmem tych ludzi, którym komunistyczne organizacje drażnią nerwy. Dla obwodów brzeskiego i białostockiego to świetna forma organizacji. Powinniśmy cieszyć się z ich powstania i rozwijać je. W warunkach tych obwodów duże znaczenie mają właśnie miejscowe kadry, utrzymujące stałą więź z narodem. Trzeba tylko, żeby obwodowy komitet antyfaszystowski utrzymywał stały kontakt $\mathrm{z}$ obkomem i przez ten był kierowany. Organizacje partyjne winny brać z organizacji antyfaszystowskich ludzi dojrzałych i aktywnych" 9.

Podporządkowanie komitetów antyfaszystowskich komitetom KP(b)B sformalizowało ich struktury i doprowadziło do wtłoczenia ich do schematów, oderwanych od rzeczywistości. Świadczy o tym m.in. fakt powoływania w partyzanckich bazach, zakonspirowanych w lasach położonych daleko od obwodu, struktur obwodowych i rejonowych tej organizacji. Włączając organizacje antyfaszystowskie do radzieckiego podziemia scentralizowano ich

8 NARB w Mińsku, zesp 3500, spr. 4, t. 258, k. 114-116; Wsienarodnaja borba Bietorussii protiw niemiecko-faszystskich zachwatczykow w gody Wielikoj otieczestwiennoj wojny, Mińsk 1984, t. II, s. 322-323.

9 Zbiory Muzeum Wielkiej Wojny Narodowej w Mińsku, sygn. 34173. 
struktury. 28 listopada 1943 r. utworzony został Białostocki Obwodowy Komitet Antyfaszystowski (BOKA) z siedzibą przy sztabie BZP w Puszczy Lipiczańskiej. Na przewodniczącego komitetu powołany został D. K. Sukaczow, dotychczasowy pełnomocnik CK KP(b)B na te obszary. Do komitetu weszli także: A. Baranowski, J. Bąk, J. Tielesz i N. Władyko.

BOKA starał się poznać i utrzymywać - poprzez specjalnych instruktorów - łączność z organizacjami antyfaszystowskimi w terenie. W tym czasie według radzieckich źródeł działały już organizacje antyfaszystowskie w rejonach: białostockim, grodzieńskim, krynkowskim, skidelskim i świsłockim. W końcu listopada 1943 r. BOKA zatwierdził składy osobowe rejonowych komitetów antyfaszystowskich: wołkowyskiego i białostockiego, a w późniejszym okresie zabłudowskiego i łapskiego. W 1944 r. powołano także rejonowe komitety antyfaszystowskie: bielski, brański i śniadowski. Według danych z 1 maja 1944 r. BOKA utrzymywał łączność z 11 komitetami rejonowymi i 86 organizacjami antyfaszystowskimi. Skupiać miały one ponad 630 antyfaszystów. Członkowie organizacji antyfaszystowskich i ich sympatycy stanowili rezerwy partyzanckie, które oceniano w obwodzie na 3 tys. osób ${ }^{10}$.

W komitetach antyfaszystowskich działali głównie członkowie b. KPZB i aktyw radziecki, powstały na tyłach, w tym również członkowie $\mathrm{KP}(\mathrm{b}) \mathrm{B}$. Ich wpływy w społeczeństwie były więc niewielkie. $\mathrm{Na}$ kierownicze stanowiska zaś wysuwano osoby przybyłe ze wschodnich obszarów. Rejonowe komitety antyfaszystowskie organizowano, tak jak komitety KP(b)B i LKZMB, w bazach partyzanckich, gdzie przebywały one do końca okupacji. Nie zawsze były one w stanie utrzymywać łączność $z$ „własnymi” rejonami. W Puszczy Różańskiej np. przy oddziale partyzanckim im. S. Budionnego działał Rejonowy Komitet Antyfaszystowski w Śniadowie, który wydawał nawet dla ludności tego rejonu gazetę i ulotki. Drukowano je w języku rosyjskim, lecz nie miało to znaczenia, gdyż wydawnictwa te nigdy do rejonu nie docierały. Były to więc kolejne fikcyjne struktury tworzone w partyzanckich bazach odległych od regionu. Tak więc i komitety antyfaszystowskie, mające stanowić ważne ogniwo łączności radzieckiego podziemia z ludnością regionu, roli tej nie spełniły.

10 NARB w Mińsku, zesp. 4, spr. 33a, t. 478, k. 46, $48 \mathrm{i}$ in. 


\section{Radziecki partyzancki „Drang nacht Westen”}

Z radzieckich źródeł wynika jednoznacznie, że „rozwój” radzieckiego podziemia odbywał się głównie w wyniku pospiesznego przerzucania na te tereny ze wschodu nie tylko organizatorów podziemia, lecz całych formacji partyzanckich: zgrupowań, brygad i oddziałów. Zaopatrywano je następnie ze zrzutów w dodatkowe uzbrojenie, amunicję i sprzęt niezbędny w podziemiu oraz w materiały polityczno-propagandowe.

1 września 1943 r. wyszło z obwodu mińskiego na Białostocczyznę BZP. W trakcie rajdu do zgrupowania dołaczały inne formacje, m.in. brygada im. Czapajewa, skierowana z rejonu puchowickiego. Włączano do zgrupowania także grupy i oddziały partyzanckie skierowane do regionu wcześniej oraz powstałe na miejscu $z$ pozostałych na tyłach wojskowych i zbiegłych z niewoli jeńców radzieckich. Po zakończeniu rajdu i zorganizowaniu w listopadzie 1943 r. stałej bazy w Puszczy Lipiczańskiej w składzie BZP były już 4 brygady i 4 operujące samodzielnie oddziały.

Jesienią 1943 r. BSzPR kontynuował przerzut „na zachód” dalszych formacji partyzanckich, zwłaszcza do obwodów białostockiego i brzeskiego. 23 listopada 1943 r. KCKP(b)B nakazał w kolejnej uchwale w sprawie dalszego rozwoju ruchu partyzanckiego w zachodnich obwodach BSRR przerzucać na te tereny $z$ obszarów wschodnich dodatkowe brygady i oddziały liczące łącznie około 12 tys. partyzantów. Jednocześnie KC zatwierdził kolejne ekipy sekretarzy rejonowych $\mathrm{KP}(\mathrm{b}) \mathrm{B}$ do obwodów białostockiego i brzeskiego. KC LKZMB został zobowiązany do podobnych działań ${ }^{11}$.

Plan działań na okres jesienno-zimowy 1943/44 r. przewidywał przerzucenie na zachód z obszarów wschodnich 18 brygad i 10 oddziałów oraz skierowanie, na Białostocczyznę przeszkolonych w Moskwie 15 grup organizatorskich, składających się z działaczy partyjnych. Według stanu na dzień 1 marca 1944 r. wyruszyło na zachód 9 brygad, 10 oddziałów i 15 grup organizatorskich ${ }^{12}$.

W ślad za BZP BSzRP skierował na Białostocczyznę kolejne formacje partyzanckie. Do rejonu kolneńskiego 4 września 1943 r. wyszedł z rejonu drissieńskiego obwodu witebskiego oddział „Biesstrasznyj”. W trakcie przeprawy przez Dźwinę został on zaatakowany koło Nowego Sioła przez Niemców i musiał stoczyć nierówną walkę, w czasie której został rozproszony.

11 Ibidem, spr. 3, t. 1247, k. 309-311.

12 Ibidem, zesp. 3500, spr. 2, t. 1026, k. 4-6. 
Rajd został przerwany, na co dowódca uzyskał zgodę BSzRP. 26 września oddział wyruszył ponownie na zachód i tym razem przy wsparciu miejscowego oddziału „Śmierć faszyzmowi” przeszedł linię kolejową Połock - Daugawpilis a następnie rzekę Dźwinę. Na początku listopada 1943 r., pokonując przeszło $300 \mathrm{~km}$, zatrzymał się $\mathrm{w}$ rejonie iwienieckim obwodu baranowickiego. 13 listopada 1943 r. za zgodą BSzRP przerwał rajd i wszedł w skład I Baranowickiej Brygady Partyzanckiej, a następnie skierowany został do rejonów nowogródzkiego i koreliczeskiego. W końcowym okresie okupacji liczył 125 partyzantów. Dowódcą oddziału w trakcie rajdu był Nikołaj Tietieryn, a od listopada 1943 r. Stanisław Zacharewicz ${ }^{13}$.

Do rejonu grajewskiego został skierowany $\mathrm{z}$ obwodu witebskiego 208 pułk im. Stalina. 10 grudnia 1943 r. wyszedł on z ukraińskich lasów w daleki rajd na zachód. W skład pułku wchodziły początkowo 3 bataliony, 4 samodzielne kompanie, pluton zwiadowczy oraz drużyny: gospodarcza i sanitarna. Łącznie liczyły one prawie 1100 partyzantów. Pułk był dobrze uzbrojony. Posiadał dwa działka $45 \mathrm{~mm}, 12$ moździerzy, 6 rusznic przeciwpancernych, 60 ciężkich i ręcznych karabinów. Była to doświadczona w walkach formacja. W ciągu 58 dni rajdu pułk przeszedł ponad $660 \mathrm{~km}$, forsu jąc 8 rzek i 3 linie kolejowe, i zatrzymał się na Polesiu. 3 lutego 1944 r. dowódca pułku otrzymał polecenie $z$ BSzRP pozostać aż do odwołania w rejonie telechańskim obwodu pińskiego ${ }^{14}$.

W grudniu 1943 r. z obwodu mińskiego wyszła do rejonów ciechanowskiego i czyżewskiego brygada im. Ponomarenki. Zorganizowano ją w listopadzie tegoż roku z oddziałów „Sokół” i im. Timoszenki, wydzielonych z II Mińskiej Brygady Partyzanckiej. Do brygady włączono jeszcze oddział im. Tałłalichina i później szwadron kawalerii im. Stalina. W lipcu 1944 r. w skład brygady włączono działający samodzielnie oddział im. Ponomarenki, przy którym był A. A. Stoma, sekretarz międzyrejonowego komitetu w Czyżewie. Brygada przed rajdem została dobrze uzbrojona i wyposażona w niezbędny sprzęt. W trakcie rajdu dwukrotnie otrzymywała zrzuty broni i sprzętu. Cały czas utrzymywała łączność z BSzRP za pośrednictwem radiostacji. Na jej wyposażeniu były m.in. 2 działka $45 \mathrm{~mm}$, rusznice przeciwpancerne, karabiny maszynowe, automaty oraz spory zapas amunicji i materiałów wybuchowych. Brygada przeszła ponad $500 \mathrm{~km}$ przez obszary czterech obwodów i w końcu czerwca 1944 r. zatrzymała się w rejonie Huty Michalin,

13 Ibidem, spr. 4, t. 258, k. 114-116.

14 Ibidem, spr. 4, t. 300, k. 148 i t. 301, k. 7, 37, 87; Wsienarodnaja borba..., t. II, s. $325-326$. 
w pobliżu brygady im. Czapajewa. Podczas postoju w rejonie Huty Michalin brygada odebrała kolejne zrzuty broni i sprzętu. Na początku lipca 1944 r. wyruszyła do rejonu świsłowskiego ${ }^{15}$.

Do rejonu łomżyńskiego skierowany został samodzielnie działający oddział im. Dzierżyńskiego. Powstał on w listopadzie 1943 r. na bazie grupy pełnomocnika KC KP(b)B na rejon łomżyński - A. F. Sokolczyka, skierowanego $z$ Moskwy na tyły wroga, oraz grup partyzanckich wydzielonych $\mathrm{z}$ innych formacji w obwodach mińskim i pińskim. Dowódcą oddziału był do czerwca 1944 r. I. A. Szutkow, a następnie G. S. Miśnik. Oddział nie dotarł do rejonu przeznaczenia ${ }^{16}$.

W sprawozdaniu KC KP(b)B z maja 1944 r. stwierdza się, że w okresie od stycznia do maja skierowano dodatkowo do zachodnich obwodów 29 oddziałów, liczących łącznie 5207 partyzantów. Kierowano je głównie do obwodów białostockiego i brzeskiego. Oprócz tego przygotowano jeszcze 9 oddziałów, liczących 1920 partyzantów, specjalnie dobranych i przeszkolonych, do działalności w rejonach łomżyńskim, śniadowskim, czyżewskim i dąbrowskim ${ }^{17}$. Autorzy sprawozdania nie wyjaśniają, na czym polegało owo „specjalne przygotowanie". Wiadomo natomiast, że miały one działać na obszarach, gdzie nie było wówczas innych niż polska narodowości.

Większość oddziałów kierowanych do regionu nie dotarła na obszary Białostocczyzny. Część z nich doszła do obwodów: baranowickiego, brzeskiego i pińskiego i tutaj, na zlecenie BSzRP, pozostała.

Dotychczasowe niepowodzenia w przerzucaniu formacji partyzanckich na zachód nie zniechęciły radzieckiego kierownictwa. Podejmowano wciąż nowe próby. Jak stwierdza raport Wydziału Operacyjnego BSzRP z 25 marca 1944 r. zalecono kierownictwom obwodów białostockiego i brzeskiego następu jące działania:

„W celu opanowania przewidzianych dla Was dyslokacji, w okresie najbliższych 10-15 dni, sformować należy 2-4 grupy po 25-50 osób każda, dobrze je uzbroić, zapewnić zapasy amunicji i skierować w celach zwiadowczych na zachód. W wypadku sprzyjającej sytuacji osiądą one w zachodnich rejonach i będą działać do nadejścia głównych Waszych sił. Kontakt z grupami utrzymywać za pośrednictwem łączników. Grupy przerzucajcie rzu-

15 NARB w Mińsku, zesp. 3500, spr. 4, t. 299.

16 Ibidem, t. 186.

17 Ibidem, spr. 29, t. 518, k. 68-72. 
tami, stopniowo zwiększając odległości rozlokowania. Uzbrojenie zrzucimy Wam w pierwsze pozwalające na loty dni" 18.

Dużo uwagi poświęcano opanowaniu Białostocczyzny. Jak wynika ze sprawozdania BSzRP z 1 marca 1944 r. zalecono kierownictwu obwodu białostockiego:

„a) z brygad i oddziałów znajdujących się w pobliżu granic obwodu białostockiego wydzielić oddziały bojowe liczące 50-100 osób i włączyć w ich skład pełnomocników do poszczególnych rejonów wraz z ich radiostarjami;

b) sformowanym oddziałom określić konkretne zadanie bojowe zmierzające do jednoczesnego wyjścia do wyznaczonych rejonów z różnych kierunków w celu zdezorientowania przeciwnika i niedopuszczenia, by mógł zgrupować swoje siły na określonym jednym kierunku. W wypadku komplikacji przy przechodzeniu linii kolejowych polecić miejscowym brygadom, by zapewniły ochronę i pomoc będącym w marszu oddziałom;

c) po przejściu oddziałów do swoich rejonów rozwinąć działalność w celu opanowania sytuacji w rejonach i przygotowania baz dla kierowanych tu później brygad;

d) rozpocząć działania bojowe na drogach kołowych i liniach kolejowych w celu dezorganizacji tyłów przeciwnika" 19.

Zalecane działania nie dawały w praktyce oczekiwanych rezultatów, dlatego w kwietniu 1944 r. w KC KP(b)B i BSzRP zapadła decyzja o zorganizowaniu w lasach grodzieńskich dużej stałej bazy przerzutowej radzieckich formacji partyzanckich na zachód. Opracowano w związku z tym plan operacyjny, w którym wykonanie tego zadania powierzono zgrupowaniu 6 brygad partyzanckich obwodu mińskiego, liczących łącznie ponad 4900 partyzantów, dobrze uzbrojonych i wyposażonych w niezbędny sprzęt i środki łączności. Do zgrupowania włączono brygady: Brygadę im. Kirowa, pod dowództwem M. I. Kreszkowa, Brygadę „Krasnoje Znamia”, pod dowództwem I. Z. Kuźniecowa, Brygadę "Razgrom”, pod dowództwem K. Ch. Bałana, Brygadę „Za Sowietskuju Biełaruś,, pod dowództwem A. N. Bazylewicza, Brygadę „Burewiestnik”, pod dowództwem M. G. Mormulewa i Brygadę „Narodnyje Mstitieli” im. Woroniańskiego, pod dowództwem G. F. Pokrowskiego $^{20}$.

\footnotetext{
18 Ibidem, spr. 2, t. 1026, k. 26-27.

19 Ibidem, k. 4-6.

20 Ibidem, zesp. 3630 , spr. 1, t. 7, k. 71.
} 
Plan operacyjny przewidywał, że w terminie 15 dni od otrzymania dyrektyw brygady wyruszą do lasów grodzieńskich. Zalecano w związku z tym skierować do północnej zony obwodu mińskiego, skąd miały wyjść brygady, przedstawiciela BSzRP, który miał za zadanie:

a) zapoznać dowódców i komisarzy brygad z zadaniami operacji;

b) powołać grupę operacyjną w składzie: dowódca N. Ch. Bałan (zachowywał dowództwo brygady), przedstawiciel BSzRP i dwóch pomocników dowódcy - ds. operacyjnych i wywiadu - których miano wyznaczyć na miejscu;

c) wspólnie $z$ dowództwem grupy operacyjnej przygotować brygady do wymarszu do lasów grodzieńskich;

d) przyjąc i rozdzielić, wspólnie $z$ dowództwem grupy operacyjnej, uzbrojenie i inny sprzęt ze zrzutów;

e) informować BSzRP o przygotowaniach do wymarszu brygad i jego przebiegu;

f) wspólnie $\mathrm{z}$ kierownictwem obwodu białostockiego opracować plan rozbicia niemieckich posterunków i opanowania lasów grodzieńskich.

Plan operacyjny przewidywał ponadto:

1. W celu zapewnienia stałej łączności podczas marszu $z$ dowództwem grupy operacyjnej przekazanie dowództwom brygad radiostacji wraz z obsługą, pochodzących ze zrzutów.

2. Dostarczenie partyzantom dostatecznej ilości uzbrojenia i sprzętu, nie mniej niż 2 tony na brygadę.

3. Zapewnienie dowództwu grupy operacyjnej niezbędnych informacji wywiadowczych $\mathrm{z}$ trasy przemarszu w celu uniknięcia walk $z$ dużymi siłami przeciwnika.

Plan zakładał, że brygada "Narodnyje Mstitieli” wyruszy do celu oddzielnie "i będzie otrzymywała rozkazy za pośrednictwem radiostacji. W kwietniu przewidziano zrzucenie brygadom i oddziałom zmierzającym do obwodu białostockiego ponad 9 ton uzbrojenia i sprzętu, w tym: 2,5 tony trotylu prasowanego, 150 tys. szt. amunicji (3,3 ton), 100 karabinów ( 0,4 tony), 60 automatów ( 0,3 tony ), 160 tys. szt. amunicji do pistoletów TT, 20 ręcznych karabinów maszynowych ( 0,3 tony), 6 kompletów moździerzy ( 0,4 tony), 4 kompletów rusznic przeciwpancernych ( 0,4 tony) a także uzbrojenie minerskie, lekarstwa, 20 kompletów umundurowania, mydło (20 kg) i tyton $(20 \mathrm{~kg})^{21}$.

21 Ibidem, k. 72-73. 
W końcowej części planu podkreśla się, że jego wykonanie będzie zależeć od zachowania dyscypliny i tajemnicy wojskowej oraz poprawnych wzajemnych stosunków z ludnością i miejscowym podziemiem.

Po opanowaniu lasów grodzieńskich znaczna część sił partyzanckich miała przejść dalej na zachód do regionu łomżyńskiego, np. brygada „Razgrom" miała działać w rejonie ciechanowieckim. Do łomżyńskiego zmierzały skierowane wcześniej oddziały: oddział im. Chmielnickiego, pod dowództwem N. W. Palczewskiego (ponad 120 osób), do rejonu brańskiego i ciechanowieckiego, oddział im. Dzierżyńskiego, pod dowództwem S. J. Stiepanowa (do maja 1944 r.) i S. F. Krzyżanowskiego (ponad 70 osób), do rejonu śniadowskiego oddział im. Budionnego, pod dowództwem A. L. Kunickiego (do grudnia 1943 r.) i A. F. Baryczewa (około 200 osób) i do rejonów augustowskiego i grajewskiego oddział im. Żukowa, pod dowództwem S. J. Tołmaczewa (do stycznia 1944 r.) i P. J. Piesockiego (ponad 100 osób).

Zgodnie z decyzją BSzRP wiosną $1944 \mathrm{r}$. w poszczególnych brygadach i oddziałach BZP zintensyfikowano prace przygotowawcze do ponownych prób przejścia na wyznaczone obszary. Na początku marca 1944 r. dowódca brygady „Wo imia Rodiny”, stacjonującej w Puszczy Różańskiej, wyszedł z 26-osobową grupą do Puszczy Białowieskiej. Tym razem udało się mu przeniknąć w głąb puszczy i zorganizować obóz partyzancki, z którego wysyłano kilkuosobowe grupy do rejonów bielskiego i brańskiego oraz zwiad do rejonów białostockiego i łapskiego. Nawiązano kontakty z ukrywającymi się oficerami i żołnierzami Armii Czerwonej, zbiegłymi jeńcami oraz zbiegami z gett. Do współpracy włączyła się też część działaczy b. KPZB oraz pozostali na tyłach „wostocznicy”. Z nich to właśnie, określonych jako „miejscowi", dowódca brygady utworzył trzy nowe oddziały: im. Dzierżyńskiego, im. Parchomienki i im. Żukowa ${ }^{22}$.

W marcu 1944 r. wyszedł z Puszczy Lipiczańskiej w rejon Białegostoku dowódca brygady im. Kalinowskiego z doborową grupą partyzantów. Nawiązał on, podobnie jak dowódca brygady „Wo imia Rodiny”, kontakt z pozostałymi na tyłach "wostocznikami”. Z nich i częściowo z miejscowych działaczy i sympatyków KPZB utworzył 1 maja 1944 r. w lasach na wschód od Białegostoku oddział partyzancki im. Kalinowskiego. Następnie przeszedł w okolice Osowca, gdzie latem 1944 r. współdziałał z oddziałami AK ${ }^{23}$.

22 Ibidem, zesp. 3500, spr. 4, t. 291.

23 Zbiory Muzeum w Grodnie, sygn. 7247 i 7345. 
W kwietniu 1944 r. również brygada im. Newskiego przeszła z Puszczy Lipiczańskiej na Świteźskie Błota, a będące w jej składzie oddziały „Za Rodinu" i im. Suworowa do lasów grodzieńskich ${ }^{24}$. Swoich emisariuszy, w asyście małych grup partyzanckich, wiosną i latem 1944 r. wysyłali do „swoich rejonów" również sekretarze KP(b)B i LKZMB. Nie docierali oni na ogół do celu. Nie znając terenu, bez wsparcia miejscowej ludności, popadali w zasadzki, organizowane przez Niemców, ginęli lub ratowali się ucieczką i następnie wracali do baz, skąd ponownie kierowano ich na zachód.

Tabela 1 przedstawia dane statystyczne o ilości radzieckich formacji partyzanckich, partyjnych grup i grup specjalnych NKGB, kierowanych do regionu białostockiego. Był to duży wysiłek organizacyjny, prowadzony z determinacją i uporem.

Tabela I. Zestawienie statystyczne radzieckich formacji partyzanckich, organizatorskich grup partyjnych i specjalnych grup i oddziałów NKGB, skierowanych ze wschodu, którym udało się dotrzeć w latach 1942-1944 do granic regionu białostockiego

\begin{tabular}{|l|c|c|c|c|}
\hline \multirow{2}{*}{ Wyszczególnienie } & \multirow{2}{*}{ Ogółem } & \multicolumn{3}{c|}{ W tym w latach } \\
\cline { 3 - 5 } & & 1942 & 1943 & 1944 \\
\hline Brygad partyzanckich & 2 & - & 1 & 1 \\
Oddziałów w brygadach & 7 & - & 3 & 4 \\
Oddziałów samodzielnie działających & 8 & $1 *$ & 6 & 2 \\
Oddziałów zza linii frontu & 1 & - & 1 & - \\
Organizatorskich grup partyjnych & 14 & - & $14^{* *}$ & - \\
Grup specjalnych NKGB & 32 & 5 & 16 & 11 \\
\hline
\end{tabular}

* W lipcu 1942 r. oddział wycofał się na wschód.

** W tym dwie grupy kierownictwa obwodowego: D. K. Sukaczowa - pełnomocnika Białostockiego Komitetu Obwodowego KP(b)B i T. N. Stryżaka - pełnomocnika KC LKZMB, skierowane wiosną 1945 r.

Źródło: Zestawienie autora na podstawie źródeł radzieckich $\mathrm{z}$ różnych zespołów.

Pomimo niepowodzeń w opanowaniu ziem polskich od wiosny $1944 \mathrm{r}$. rozpoczęto intensywne przygotowania do przejmowania władzy w terenie, w tym również na Białostocczyźnie. W kwietniu 1944 r. powołana została

24 NARB w Mińsku, zesp. 3500, spr. 4, t. 290, k. 60 i in. 
specjalna grupa operacyjna na obwód białostocki na czele z D. K. Sukaczowem, mająca za zadanie odbudowę radzieckich władz terenowych, tj. obwodowego, miejskiego i rejonowych komitetów wykonawczych. Przygotowywano też grupy operacyjne dla miast i rejonów. Członków grup operacy jnych przeszkolono na specjalnych kursach w Moskwie, a następnie w Homlu.

W maju 1944 r. powrócił na tereny okupowane D. K. Sukaczow - jak sam pisze - tym razem już jako przewodniczący obwodowego komitetu wykonawczego rady delegatów ludu pracu jącego w Białymstoku ${ }^{25}$. Był on tylko organizatorem obispołkomu. 8 lipca 1944 r. Biuro KC KP(b)B zatwierdziło na przewodniczącego Obispołkomu w Białymstoku Piotra Iwanowicza Ratajko - zastępcę przewodniczącego Rady Komisarzy Ludowych BSRR oraz skład Biura Komitetu Obwodowego KP(b)B. Do biura obkomu weszli: Andrej Pietrowicz Elman, Nikołaj Iwanowicz Roditielew - sekretarz KC, Piotr Iwanowicz Ratajko, Iwan Pawłowicz Muraszkin, Daniło Kirejewicz Sukaczow i Iwan Siergiejewicz Krawczenko ${ }^{26}$.

\section{Grupy i oddziały dywersyjno-zwiadowcze NKGB}

Prace związane $z$ działalnością NKGB na tyłach niemieckich rozpoczęto w pierwszych dniach wojny i prowadzono w bardzo trudnych warunkach, podczas wycofywania się Armii Czerwonej na wschód, pod silnym naporem wojsk hitlerowskich. Pracownicy NKGB do działalności na terenach okupowanych nie byli przygotowani, gdyż radziecka doktryna wojenna zakładała, że po wybuchu wojny działania wojenne przeniesione zostaną na terytorium wroga. Brakowało też doświadczonych kadr kierowniczych, które przerzedziły represje $z$ końca lat trzydziestych. Jednak pomimo trudności już w pierwszych dniach wojny rozpoczęto starania w celu powołania grup i oddziałów NKGB i skierowania ich na okupowane obszary. 26 czerwca 1941 naprędce zorganizowano w Mohylowie, gdzie ewakuował się NKGB BSRR, 14 oddziałów specjalnego przeznaczenia, liczących łącznie ponad 1 tys. osób ${ }^{27}$. Przerzucano je na tyły niemieckie, lecz na skutek niedostatecz-

25 D. K. Sukaczow, W bojach i pochodach, w: W priniemanskich lesach. Wspominaia partizan $i$ podpolszczykow, Mińsk 1975, s. 35. W styczniu 1944 r. D. K. Sukaczow wysłany został za linię frontu do KC KP(b)B w celu sprawdzenia działalności w obwodzie białostockim.

26 NARB w Mińsku, zesp. 4, spr. 61, t. 51, k. 15-16.

27 Ibidem, zesp. 3500, spr. 4, t. 346, k. 87. 
nego przygotowania bojowego, braków w uzbrojeniu i sprzęcie, a zwłaszcza braku środków łączności, nie mogły one spełnić oczekiwań i zorganizować na okupowanych terenach sprawnie funkcjonujących struktur.

Do wiosny 1943 r. większość grup i oddziałów kierowana była na obszary Białorusi, później, zwłaszcza od lata 1943 r., głównie już na północno-wschodnie ziemie Polski. Część grup i oddziałów działających na Białorusi otrzymała rozkaz przejścia na zachód. Tak więc grupy i oddziały ze wschodu przesuwały się na północno-wschodnie ziemie Polski, gęsto je pokrywając. W lipcu 1944 r. z 226 grup i oddziałów liczących 3104 osób aż 177 (2456 osób) działało na ziemiach polskich, tj. ponad $78 \%$ grup i oddziałów i $79 \%$ osób. Na ziemiach polskich najwięcej grup i oddziałów NKGB skierowano do obwodów białostockiego - 32, pińskiego - 22 i wileńskiego - 2028. Grupy kierowane do obwodu białostockiego były najliczniejsze, liczyły średnio po 11 osób, podczas gdy grupy kierowane do innych obwodów - średnio po 6 osób. Część grup działających na Białorusi, zanim trafiła na ziemie polskie, wycofywana była za linię frontu, gdzie przeszła dodatkowe przeszkolenie, po którym przerzucano je znów na tyły. Dodać należy, że znaczną część grup i oddziałów NKGB i NKWD ZSRR kierowano również na ziemie polskie. Część ich znalazła się w obwodzie białostockim. Białostocczyzna była pod szczególną „opieką" radzieckich służb specjalnych.

Grupy i oddziały NKGB prowadziły walkę z Niemcami i wywiad na rzecz Armii Czerwonej, lecz głównym ich zadaniem był kontrwywiad i wywiad polityczny. Wspierały one radziecki ruch partyzancki, przejmując w praktyce nie tylko partyzancki kontrwywiad i strzegąc „czystości” kadr partyzanckich, lecz również inspiru jąc działania związane $z$ walką $z$ wrogami wewnętrznymi, zwłaszcza $z$ działającym na omawianych obszarach polskim podziemiem. W wydziałach specjalnych sztabów radzieckiej partyzantki na Białorusi, zajjmujących się wywiadem i kontrwywiadem oraz walką $z$ wrogami wewnętrznymi, pracowało 564 pracowników NKGB, głównie w formacjach działających na ziemiach polskich. Informacje o tej działalności są niestety w archiwach NKGB, które są nadal niedostępne.

Akcje terrorystyczne były skierowane, jak to wówczas określano, przeciwko „wrogom władzy radzieckiej”, „elementom kontrrewolucyjnym” oraz wszelkiego rodzaju „swołoczy”. Są to określenia dosyć pojemne i można było faktycznie dokonać rozprawy z każdym, kto stanął na drodze władzom radzieckim. Stosowany przez grupy i oddziały NKGB terror nie wynikał tylko

28 Ibidem, t. 329 , k. 14, 18. 
z warunków wojennych, stanowił on metodę działania, istotny środek do osiągania celów. W końcowym, zbiorczym sprawozdaniu z działalności grup i oddziałów NKGB wymienia się m.in. że ustalono 37446 osób, określanych jako „wrogi element”. W liczbie tej było 6109 niemieckich agentów, 14377 „zdrajców”, 16960 „wrogów władzy radzieckiej” i 338 współpracowników niemieckiego wywiadu. W wymienionym sprawozdaniu stwierdza się też, że rozstrzelano 801 niemieckich agentów i 1276 „zdrajców ojczyzny” oraz wykryto 33 przywódców kontrrewolucyjnych organizacji i ich agentów ${ }^{29}$.

W celu rozpoznania polskiego podziemia NKGB wykorzystywało sąsiedzkie kontakty, jakie utrzymywała $\mathrm{AK}$ z radzieckimi oddziałami partyzanckimi. „Przysłani specjalnie z Rosji NKWD-ziści - pisze J. Prawdzic-Szlaski, komendant okręgu nowogródzkiego AK - budowali w terenie, z zachowaniem jak najdalej idącej konspiracji, siatkę wywiadu nastawioną na rozpracowywanie czynnie pracujących członków polskiego ruchu podziemnego i likwidowali przywódców (np. zorganizowany zamach na mjra »Kotwicza-Macieja «, zamach na Kazimierza Klukowskiego, zamach na kwatermistrza okręgu, ppor. »Dunina «, zamach na »Jana«, prawą rękę kwatermistrza okręgu, usiłowanie zamachu na komendanta kompanii konspiracyjnej rtm. "Antoniego «", na komendanta obwodu Szczuczyn i cały szereg innych). Stałą siedzibą NKWD była Puszcza Nalibocka i Lipiczańska ${ }^{30}$. NKGB likwidowało również działaczy białoruskiego ruchu niepodległościowego.

Grupy i oddziały NKGB, penetrując przeciwników, stworzyły rozległą sieć konfidentów i informatorów. Według danych $z$ niepełnego przecież wykazu grup i oddziałów działających na ziemiach polskich było ich ponad 2680. Zdobywane $\mathrm{w}$ ten sposób informacje przekazywano do centrali w Moskwie, a część dotycząca polskiego podziemia i innych wrogów władzy radzieckiej - także obwodowym centrom radzieckiego podziemia.

Bezpośrednio do regionu białostockiego skierowano, według radzieckich źródeł, 32 oddziały i grupy NKGB. Większość tych grup dotarła do wschodnich obszarów regionu lub na wschodnie obszary do regionu przylegające. Według danych z 11 grup, liczyły one w latach 1943-1944 od 108 do 633 osób, zorganizowały siatkę agenturalną liczącą ponad 500 osób ${ }^{31}$. W regionie białostockim działały, m.in. następu jące grupy NKGB: „Czerwonnyje”

29 Ibidem, k. 15-16.

30 J. Prawdzic-Szlaski, Nowogródczyzna w walce 1940-1945, Londyn 1976.

31 NARB w Mińsku, zesp. 3500, spr. 4, t. 348, k. 4-44; A. K. Sokołow, Oni diejstwowali pod raznymi psiewdonimami, Mińsk 1994, s. 176. 
(dowódca N. W. Czernoniebow), „Dalnije” (dowódca N. A. Chmielewcew), "Drużba” (dowódca I. A. Żołobow), „Ilińskogo" (dowódca N. S. Iliuszkin), "Patrioty" (dowódca D. I. Manuiłow), „Rozowa” (dowódca W. S. Cwietkow), „Sława” (dowódca I. W. Wasiuk), „Wpieriod” (dowódca P. M. Sołatkij) i "Zapadnyje" (dowódca F. S. Piljugin) oraz dwa oddziały: „Nowatory” (dowódca B. M. Litwinskij), liczący 126 osób i „Wiest” (dowódcy A. G. Mironow (do 16 X 1943) i L. A. Agabiekow), liczący 250 osób.

Reasumując należy stwierdzić, że oddziały i grupy NKGB prowadziły na szeroką skalę działania związane $z$ oczyszczaniem terenu $z$ „wrogów władzy radzieckiej". Stanowiły one ważne ogniwo w realizacji radzieckich starań o ponowne zawładnięcie wschodnimi ziemiami polskimi, w tym i regionem białostockim. Współuczestniczyły jednocześnie w kreowaniu radzieckiej polityki w „sprawie polskiej”, przekazując radzieckiemu kierownictwu stosowne informacje o postawach politycznych ludności, o trwającym oporze wobec radzieckiej polityki, o polskich organizacjach niepodległościowych. Ważną kwestią będzie w dalszych badaniach ustalenie, na ile były to wiarygodne informacje i w jaki sposób je uzyskano.

\section{Radziecka propaganda w regionie białostockim w latach 1943-1944}

Propagandę traktowano w radzieckim podziemiu jako jeden $\mathrm{z}$ ważnych środków realizacji radzieckich celów politycznych. Prowadzono ją pod ogólnymi hasłami walki z okupantem, akcentowano wspólnotę celów w tej walce i jedność narodów słowiańskich. Głoszono, że radziecka polityka jest „jedyną słusz̨ną i sprawiedliwą polityką", służącą ludziom pracy wszystkich narodów. Jednocześnie wskazywano, że radzieckie podziemie - jak odnotował to szef sztabu BZP w dzienniku - obok broni ma inny skuteczny oręż swoją (tj. komunistyczną) ideologię32.

Głównymi formami szerzenia ideologii komunistycznej i radzieckiej polityki w podziemiu była podziemna prasa i inne wydawnictwa oraz ustna propaganda. Prasę podziemną wydawały głównie ośrodki partyjne i komsomolskie, rzadziej inne struktury podziemia. Nawet wtedy, gdy w podtytule figurowała inna struktura podziemia, np. komitet antyfaszystowski, faktycznym wydawcą był komitet $\mathrm{KP}(\mathrm{b}) \mathrm{B}$.

32 I. Sienkiewicz, Rejd na Zachad, „Połymia”, 1969, n r 9. 
7 listopada 1943 roku ukazał się pierwszy numer „Biełostokskoj Prawdy", którą określano w podtytule: „Organ Białostockiego Obkomu KP(b)B i Obwodowej Rady Delegatów Ludu Pracującego". Gazetę redagował S. Majchrowicz, skierowany do tego celu z Moskwy wraz ze zgrupowaniem. "Biełostokskaja Prawda" wychodziła systematycznie co kilka dni, w małym formacie ( $15 \times 21)$, o objętości 4-6 stron. Ostatni, podwójny numer 61-62 ukazał się z datą 6 lipca 1944 r.

W tym samym czasie wydawano też podziemną gazetę LKZMB „Mołodoj Partizan”. W podtytule umieszczono napis „Młodzieżowa gazeta antyfaszystowska obwodu białostockiego". Pierwszy jej numer ukazał się już 28 października 1943 r. w trakcie rajdu. Był to numer specjalnie przygotowany na 25-lecie Komsomołu. Jej redaktorem był Jakow Koczan, dziennikarz wydawanej w Moskwie gazety „Sowietskaja Biełoruś”. „Mołodoj Partizan" wychodził raz w tygodniu w nakładzie 300-400 do 500 egzemplarzy. Jedynie nr 1, okolicznościowy, ukazał się w podwójnym nakładzie. Ukạzało się 55 numerów tego pisma.

Obie wymienione gazety były drukowane w języku rosy jskim w drukarni BZP, którą skierowano wraz z organizatorami podziemia z Moskwy.

Obok wymienionych dwóch gazet o zasięgu obwodowym wydawano 15 gazet rejonowych. M.in. w 1943 r. rozpoczęto wydawanie gazet - organów KP(b)B w rejonach: świsłockim - „Świsłocka Prawda”, śniadowskim „Za Naszu Pobiedu”, skidelskim - „Krasnoje Znamia”. W 1944 r. wydawały swoje gazety również komitety $\mathrm{KP}(\mathrm{b}) \mathrm{B}$ w rejonach: brańskim - „Wpieriod na Wraga”, grodzieńskim - „Za Sowietskuju Rodinu”, łapskim - „Znamia Pobiedy” (do 6.IV.1944 - „Krasnoje Znamia”), czyżewskim - „Patriot Rodiny” i łomżyńskim - „Smierć faszyzmowi”. Swoje gazety wydawały też niektóre komitety antyfaszystowskie.

Podziemne gazety rejonowe ukazywały się w języku rosyjskim, nieregularnie, w małym formacie i niskim nakładzie. Pisano w nich głównie o walce z Niemcami i na frontach, i na tyłach oraz o pracy politycznej wśród ludności. Dominowały w nich materiały ogólne, rzadko publikowano informacje dotyczące regionu. W większości były to przedruki z prasy centralnej.

Poszczególne komitety oraz Obwodowy Sztab Ruchu Partyzanckiego wydawały również ulotki i odezwy do ludności oraz komunikaty Radzieckiego Biura Informacyjnego o sytuacji na froncie w serii: „Ostatnie wiadomości”. Drukowano je w małych formatach, częściowo jednostronnie, żeby można je było rozklejać na parkanach, ukazywały się one w olbrzymiej większości w języku rosyjskim. Ich nakład, ze względu na brak papieru i technikę druku, był niski. Łącznie radzieckie podziemie kolportowało w regionie po- 
nad 260 tytułów różnych odezw i ulotek drukowanych lub odbijanych na powielaczach, maszynach do pisania lub pisanych ręcznie ${ }^{33}$. Znaczna ich część zawierała komunikaty Radzieckiego Biura Informacyjnego o sytuacji na froncie, hasła nakazujące bojkot zarządzeń władz okupacyjnych i wzywające do walki $z$ faszyzmem.

Część odezw adresowano do ludności polskiej. Jak informował D. K. Sukaczow komitet obwodowy KP(b)B wydał do 300 tys. egzemplarzy odezw i ulotek w języku polskim, wzywających do walki z Niemcami ${ }^{34}$. Uważano bowiem, zgodnie $z$ tezami propagandowymi, że walczyć można tylko w szeregach radzieckiego podziemia, że w polskim podziemiu walki takiej nie prowadzi się, że odciąga ono od walki, a nawet z Niemcami współpracuje. Jednocześnie przypominano Polakom, że kwestia granicy wschodniej rozwiązana została ostatecznie w 1939 r.

Prasa i inne wydawnictwa przeznaczone dla zachodnich obszarów Białostocczyzny nie różniły się pod względem formy i treści od pozostałej, a przecież na tych terenach żyła głównie ludność polska, której postawy i cele były inne, walczyła ona aktywnie z okupantem, by żyć w wolnej i niezależnej Polsce.

W ostatnich miesiącach okupacji w pracy politycznej i propagandowej uwagę koncentrowano na kwestiach bezpośredniego zabezpieczenia powrotu władzy radzieckiej na obszary Białostocczyzny. Głoszono przy tym, że wraz $z$ wyzwoleniem przez Armię Czerwoną nastąpi w regionie „swobodne i radosne życie". Nowym elementem jest to, że w wydawanych odezwach i ulotkach, obok komitetów partyjnych, do ludności zwracają się już przedstawiciele „radzieckich władz terenowych”.

Reasumując należy stwierdzić, że oddziaływanie radzieckiej propagandy, zarówno zę względu na jej treści, jak i formę (sloganowe hasła w obcym języku) było znikome. Do tego docierano z nią tylko do części ludności zamieszkującej na wschodnich obszarach regionu, w ostatnich miesiącach okupacji.

33 Liczbę ulotek ustalono na podstawie zachowanych egzemplarzy. Według relacji niektórych uczestników walk $\mathrm{z}$ faszyzmem było ich znacznie więcej.

34 NARB w Mińsku, zesp. 2, t. 49, k. 167. 


\section{Fiasko radzieckich starań o ponowne opanowanie Białostocczyzny w latach 1943-1944}

Kierowani na ziemie polskie radzieccy partyzanci zastawali tu zupełnie inną sytuację, niż im zapowiadano przed wymarszem. Diametralnie odmienna była zwłaszcza sytuacja na Białostocczyźnie. Pomimo formalnej unifikacji tych ziem z BSRR w 1939 r. zachowały się tu istotne różnice w strukturze społeczno-gospodarczej oraz w postawach i świadomości ludności. Antypolska polityka ZSRR i stosowane represje nie zdołały pozbawić Polaków dominującego wpływu w regionie. Partyzanci radzieccy zetknęli się na polskich ziemiach $\mathrm{z}$ dobrze zorganizowanym, głęboko tkwiącym w terenie i wszechstronnie wspieranym nie tylko przez Polaków polskim podziemiem. Wejście do regionu radzieckiego podziemia i jego działalność polityczno-propagandową traktowano jako „akt skierowany przeciwko państwowości polskiej" 35. Uznanie tych ziem za radzieckie traktowano jako kontynuację agresji z 1939 r. Szczególnie raziło miejscową ludność oskarżanie - wbrew faktom - polskiego podziemia o bezczynność $w$ walce $z$ okupantem a nawet „wspieranie” Niemców. Polskie podziemie walczyło przecież z Niemcami wszystkimi dostępnymi środkami i przeciwstawiało się skutecznie eksterminacyjnej polityce okupanta.

Czy w takiej sytuacji, przy silnym i wspieranym przez ludność polskim podziemiu i braku szerszego oparcia wśród miejscowej ludności, radzieckie podziemie miało szansę wejścia na te tereny i opanowania ich? Hasła, z jakimi wchodziło ono na te tereny, nie rokowały szans powodzenia. Restytucja stosunków, siłą wprowadzonych w 1939 r., nie znajdowała zwolenników. Nie było też szans na „stworzenie" sobie liczących się sojuszników. Komuniści, skompromitowani wspieraniem antypolskiej polityki radzieckiej w latach 1939-1941, nie mieli na tych terenach istotnych wpływów. Nie można też było liczyć na "podporządkowanie" sobie polskiego podziemia. A jednak z wejścia na Białostocczyznę nie rezygnowano. Z determinacją i uporem wciąż kierowano nowe siły i środki, by ten cel osiągnąć.

Pomimo usilnych starań i wielokrotnych prób nie udało się radzieckiemu podziemiu wejść na stałe na obszary Białostocczyzny. Nie osiągnęły też na tych terenach zakładanych celów grupy specjalne NKGB. Tylko część skierowanych tu sił dotarła do Puszczy Lipiczańskiej i Różańskiej, skąd następnie pojedyncze grupy i oddziały próbowały iść dalej, lecz bez większych

35 Archiwum Akt Nowych w Warszawie, Oddział VI, 202/III-134, k. 368. 
rezultatów. Inne pozostały w obwodach baranowickim, brzeskim, pińskim i wileńskim. Stwierdzenie S. Prytyckiego, i w ślad za nim innych autorów, że pomimo trudności radzieckie podziemie wykonało na tym terenie swoje zadanie, nie da się racjonalnie uzasadnić ${ }^{36}$.

Prowadzona na Białorusi od lata 1943 r. rejonizacja i centralizacja struktur podziemia była na tych terenach nie tylko sprzeczna $z$ istotą konspiracji i zasadami jej efektywności, lecz i oderwana od gleby, na której może rozwijać się ruch partyzancki. Przerzucane na nieznane tereny radzieckie formacje zatracały siłę wynikającą ze znajomości terenu i poparcia miejscowej ludności. Zmuszało to je do szukania nowych sposobów „utrzymania się" w terenie. Brygady i oddziały kryły się w dużych, trudno dostępnych masywach leśnych obwodu baranowickiego i brzeskiego i działały tylko małymi patrolami, bez trwałej więzi i stałego wsparcia miejscowej ludności. Nie wykonano opracowanego $\mathrm{z}$ rozmachem planu operacyjnego w sprawie zorganizowania w lasach grodzieńskich bazy partyzanckiej. Skierowane w tym celu brygady partyzanckie po drodze, daleko przed celem, „osiadły” w obwodach wschodnich.

Analiza przebiegu rajdu poszczególnych formacji, dokonana na podstawie zachowanych sprawozdań dowódców oraz wspomnień i relacji uczestników, wskazuje, że „marsz na zachód” nie przebiegał wzorowo i sprawnie jak oceniaja to autorzy historii ruchu partyzanckiego na Białorusi ${ }^{37}$. Partyzanci mieli duże trudności w rozwiązywaniu spraw aprowizacji na nowych, nieznanych terenach oraz $\mathrm{w}$ nawiązywaniu łączności $\mathrm{z}$ miejscową ludnością. Często musieli z braku miejscowych przewodników krążyć po lasach i bagnach, co w istotny sposób utrudniało, a niekiedy uniemożliwiało przemarsz, lub popadali w zasadzki organizowane przez Niemców.

Wśród partyzantów, pędzonych na nieznane im ziemie, rodziły się uzasadnione wątpliwości. Jeśli rzeçzywiście celem była walka z Niemcami, tak jak oficjalnie ogłoszono, to czy nie lepiej było bić Niemców na własnej ziemi, wykorzystując znajomość terenu i wsparcie ludności? Jeśli natomiast trzeba było zaktywizować walkę $\mathrm{z}$ okupantem na tych terenach - takie hasła też głoszono - to czy nie wystarczyło skierować tu grupy organizatorów i uzbrojenie? Dlaczego kierowano całe zgrupowania, brygady i oddziały i do tego starano się je równomiernie rozmieszczać w dowojennych rejonach, niezależnie od warunków terenowych. Podkreślić też należy,.że stwierdzenie o „małej

36 S. O. Prityckij, Za swobodu i niezawisimosć rodiny, w: Niepokorionnaja Bietorussija, Moskwa 1963, s. 308 i in.

37 Wsienarodnaja borba..., t. II, s. 328-329. 
aktywności w walce $\mathrm{z}$ okupantem" miejscowej ludności jest nieprawdziwe. Walkę z Niemcami prowadzono tu od początku okupacji we wszystkich znanych formach. Obok różnorodnych form biernego i czynnego oporu cywilnego istniała cała sieć ogniw terenowych ZWZ-AK, z rozbudowanymi strukturami w okręgach, inspektoratach obwodowych, obwodach, rejonach i placówkach. Działały też struktury partyzanckie i dywersyjne ( "Wachlarz”, „Kedyw").

Nie udało się też radzieckiemu podziemiu wyeliminować polskiego podziemia. Podziemie radzieckie przebywało na stałe w ukrytych bazach w lasach, polskie zaś we wsiach i miasteczkach, ukrywane przez ws pierającą je ludność. Było ono dla wielu mieszkańców tych ziem znakiem sprzeciwu wobec radzieckiej polityki przemocy i - co ważne - nadzieją na zmianę sytuacji. Nie zdołano też rozpracować konfindencyjnie siatki konspiracyjnej ZWZ-AK, pomimo skierowania na te tereny dużej ilości specjalnych grup NKGB i zorganizowania w partyzanckich sztabach specjalnych wydziałów. Pomimo dużych wysiłków penetracja polskiego podziemia była ograniczona.

Reasumując należy stwierdzić, że dopiero wiosną i latem 1944 r. niewielka część radzieckiego podziemia weszła na wschodnie obszary Białostocczyzny i nawiązała łączność z osobami związanymi przed wojną z ruchem komunistycznym. Nawiązano też kontakty $z$ istniejącymi tu komitetami antyfaszystowskimi. Kontakty dotyczyły niewielkiej ilości osób i nie można ich uznać za „wejście w teren”. Obok złych doświadczeń z lat 1939-1941 i wnoszonej przez radzieckie podziemie obcej ideologii odgradzało je od ludności wrogie traktowanie polskiego podziemia, z którym olbrzymia większość ludności wiązała swoje nadzieje, w którym aktywnie uczestniczyła i które wszystkimi środkami wspierała. Traktowanie „wrosłego w teren" masowego polskiego podziemia przez przybyszów jako „agentów Londynu”, prowadzących rzekomo "grę z okupantem", nie mogło zapewnić im poparcia, zwłaszcza że głoszono nadal, że są to radzieckie ziemie, włącznie z Łomżyńskiem i tą częścią Białostocczyzny, gdzie nie było ludności białoruskiej.

26 lipca 1944 r., podczas rozmów delegaci PKWN z rządem radzieckim, zapadła decyzja o skorygowaniu ustalonej w 1939 r. zachodniej granicy ZSRR zgodnie z tzw. Linią Curzona. Większa część regionu białostockiego pozostała Polsce. Wiadomość o zmianach dotarła do wyzwolonego 27 lipca 1944 r. Białegostoku w końcu lipca. Do tego czasu powołano na wyzwolonych obszarach ogniwa terenowe radzieckich władz. Między innymi w Białymstoku rozpoczęła działalność Miejska Rada Delegatów Ludu Pracującego, w terenie próbowano uruchamiać rady rejonowe i wiejskie. Na wyzwolonych obszarach prowadzono mobilizację roczników urodzonych w la- 
tach 1894-1926 do Armii Czerwonej. W związku z tym uruchomiono aparat propagandowy i podjęto szerokie działania organizacyjne. Przedstawicieli polskiego państwa podziemnego, ujawniających się w akcji „Burza”, aresztowano i zesłano do obozów.

Brak dostatecznej ilości źródeł, zwłaszcza dostępu do wszystkich źródeł NKWD (NKGB), nie pozwala jeszcze jednoznacznie stwierdzić, kto forsował walkę o ponowne włączenie Białostocczyzny w skład ZSRR - władze Białoruskiej SRR czy władze ZSRR. W radzieckich ocenach Białostocczyznę już w 1920 uznano za teren niepolski. Dlaczego jednak zrezygnowano z większości tego terenu w 1944 r.? Sądzę, że głównym czynnikiem, który zadecydował o tym, była niezłomna postawa mieszkańców regionu, zarówno w latach 1939-1941, jak i w latach okupacji niemieckiej. Piętrzące się trudności w opanowaniu tego terenu skłoniły władze ZSRR do rezygnacji. Pewną rolę mogła też odegrać chęć zademonstrowania „kompromisowego” stanowiska. J. Stalin, gdy osiągnął swój cel w „sprawie polskiej”, zgodził się na mały gest wobec nowego polskiego „sojusznika”, licząc też zapewne na efekty propagandowe i jego wdzięczność. 